in Spain, but a consequence of the purges within the People's Commissariat for Foreign Affairs (NKID) completely independent of the war in Spain. The fate of the consul's surviving son, Anton, his difficult trajectory and tireless defence of his late father, including the publication of a little-known memoir, is skilfully incorporated into the narrative.

Informing this highly original and important study is a singularly impressive depth of research that draws upon declassified documentation in the Russian Federation and Spanish national and regional holdings, as well as British archival sources and an exhaustive traversal of the contemporary press in multiple languages. The Russian archives consulted include the former party archive, now the Russian State Archive of Socio-Political History (RGASPI), and the military, state, and foreign affairs archives. Missing from this study, lamentably, is today's presidential archive, parts of which are now declassified and available, and which may have shed additional light on the role of the consulate in the Spanish Civil War. In terms of secondary studies, Puigsech demonstrates due mastery, and the bibliography is as up-to-date as one may reasonably expect; the most recent literature in Russian, Spanish, Catalan, French, and English is represented. The author is especially adept in his use of Angel Viñas, whose tetralogy of works on the Soviet Union and the Spanish Civil War (2006-2009) may be considered the definitive culmination of scholarly revision of the field. Yet Puigsech demonstrates that Viñas's studies have only hinted at the complexities of the role of the Barcelona consulate, finally addressed in this excellent, indispensable monograph.

\title{
Daniel Kowalsky
}

School of History and Anthropology, Queen's University Belfast is University Square, Belfast BT7 iPA, United Kingdom E-mail: d.kowalsky@qub.ac.uk

Drew, Allison. We are no longer in France. Communists in colonial Algeria. [Studies in Imperialism.] Manchester University Press, Manchester [etc.] 20I4. xv, 3 I I pp. £75.00. doi:10.1017/S00208590I 5000577

Allison Drew is Professor of Politics at the University of York, and a specialist in the social and liberation movements of South Africa. The initial idea for the present book was to compare communist activism in two different colonial situations: Algeria and South Africa. In these two territories, characterized by a strong presence of settlers, communists faced a series of similar challenges, such as their relationship with nationalist movements, the question of armed struggle, and the situation within their own organizations (which brought together "natives" and Europeans). But, as Drew says, "Algerian communism needs to be examined on its own terms before it can be compared with other communist experiences" (p. xi).

In view of previous works on the subject, especially Emmanuel Sivan's Communisme et nationalisme en Algérie (Paris, 1976), which is still highly influential in current historiography, this assertion is important. Indeed, most studies to date have not really analysed Algerian communism "on its own terms", but rather have examined, from a critical point of view, the relationship between Algerian nationalists and the French Communist Party (PCF, of which the Algerian communist organization was a local section until 1936). 
Moreover, Sivan's work - influenced by the analysis of the contradictions of "left-wing colonizers" put forward by the writer Albert Memmi in The Colonizer and the Colonized (French original, 1957) - overestimated the racial gap between Europeans and Algerians inside the Algerian Communist Party (PCA); whereas, according to Drew, "individual attitudes are too complex and variable to be explained by reference solely or even primarily to ethnic or national background" (p. 2). Distancing itself from the usual polemical judgements about the PCA's "failure" and "lag" during the war of independence, or its so-called "assimilationist" policy, the book addresses Algerian communism as an object of political and social history, and as a full component of Algerian society and its political landscape.

Much more than a simple overview of Francophone historiography for Anglophone readers, Drew's book offers a consistently historical perspective and draws on rich primary materials. It uses French "overseas" state archives, memoires recently published by former Algerian communists, and interviews conducted with others. With this newly excavated archive material, original perspectives are opened on Algerian communism and Algerian colonial society in general. In addition, the use of the Comintern archives in Moscow enables the author to see beyond the usual PCA-PCF binary, and to revisit the relationship during the interwar period between the Communist International and local activists, who sometimes wrote directly to the Comintern in order to comment on or complain about the policy of the PCF in Algeria. Some of these documents can help to improve the understanding of the evolutions and sometimes abrupt changes of the PCA's political line, considering the respective involvement of "Moscow", the PCF, and Algerian communists anew. Moreover, archival material on the British consulate in Algiers - a promising source for an interconnected imperial history - offers a fascinating perspective on colonial Algeria's political evolution, sometimes more lucid than the French intelligence service's reports themselves. Finally, the documentation produced by South African activists about the Algerian national liberation movement is also included and indicates the potential of the comparative study Drew aims to work on.

One of Drew's strongest and most innovative assertions is that, unlike communism in other contexts, communism in colonial (and post-colonial) Algeria pursued the goal of "[pushing] the boundaries of public political space" (p. 270) by struggling for "a vibrant civil society and pluralist democracy" (p. 8). This analytical perspective allows her to focus not only on the PCA's political line and "official stance", but to consider its activists' practices and "its internal contestations" (p. I04). Thus, she documents the numerous methods male and female communist activists used to extend the political space, entering Muslim places of sociability where they adjusted their practices and were sometimes able to achieve full acceptance, as was the case with interventions in rural areas around Tlemcen. Furthermore, Drew underlines the importance of the PCA's struggle against repression in all its forms, especially after World War II, and the part it played in the PCA's radicalization, its recruitment of young Algerians, and its will to unite with nationalists.

According to Drew, the vision of democratic rights elaborated by the PCA "reflected a dual notion - freedom from repression and freedom to develop", and "the PCA allowed members space for discussions", unlike the nationalist movement, which "left little space for effective debate within its organisations" (p. I46). Though the idea of the PCA's internal "democracy" should be nuanced and compared to the freedom of debate at times existent inside the third force of the national liberation movement (the Union Démocratique du Manifeste Algérien), the PCA's daily life was indeed far from “totalitarian”, even during the clandestine periods of Vichy and the Algerian war. 
The book also provides new and stimulating information on the social struggles led by communists, especially in the interwar period. The most original chapter (chapter 3 ) offers a fascinating study of communist activism in struggles for land at the beginning of the $1930 \mathrm{~s}$ in a rural area, the Mitidja. In this chapter, Drew's pioneering investigation of Comintern archives, confronted with other sources, provides a unique perspective on the tensions between the Colonial Commission of the PCF and local communists, as well as on the alliances between peasants and urban activists, which led to a form of syncretism between the underground "self-government" system of the peasants, the struggle against land expropriation, references to Islam, and Marxism. Even if the Mitidja's experience was ephemeral, this study highlights a larger phenomenon: the pragmatism of some communist activists and the complexity of their political practices, while simultaneously using electoral campaigns and clandestine activism, approaching Islamic organizations, and linking propaganda for class struggle with calls for Algeria's independence. Some readers will regret the fact that the book does not delve further into the legacy of this interwar multiform activism in Blida and the Mitidja, where the PCA won a local election amongst Algerians at the beginning of the war of independence, while at the same time organizing a paramilitary clandestine network. This aside, chapter 3 proves the interest of local studies in building a more concrete and complex view of Algerian communist policy, especially amongst workers and in rural areas in which communists sometimes succeeded in "opening up new areas of political space” (p. I 57), even at a moment when nationalist activists had not yet taken root in Algeria.

Regarding the war of independence, chapters 7, 8, and 9 revisit some of the historiographical prejudices influenced by the official history written by the National Liberation Front (FLN, which led the struggle during the war). Thus, Drew's research challenges Sivan's claims "that the PCA's support for the anticolonial struggle was both belated and abrupt, thereby contributing to its collapse" (p. 269). The "collapse" of the PCA after I957 (which was never complete) can indeed mostly be linked to the French state's "ruthless repression - constant surveillance, arrest, internment and imprisonment” (p. 270), which resulted from Cold War paranoia and the PCA's field presence. Moreover, breaking with the idea that communists could (and should) have joined the FLN and dissolved their organization at the very beginning of the war, Drew mentions several facts that prove the hostility of many FLN members towards communists or former communists, especially in the maquis, where many of them were threatened and even murdered by their brothers in arms. As Drew writes, "the depth of anti-communism amongst many FLN leaders would presumably have made entryism as difficult an option as organisational autonomy" (pp. 269-270). Nevertheless, the PCA organized its own armed groups in both rural and urban areas, until the PCA-FLN agreement of summer 1956 turned PCA's armed activists into FLN members.

The actions of these groups should not be underestimated. Drew stresses the fact that there were Europeans amongst the communists who joined the armed struggle, but her assertion, influenced by Sivan's work, that most of them were former underground activists of 1940 or "intellectuals" must be revised: as the records from the military justice court archive for 1956-1959 show, most Europeans involved in Blida, Oran, and Constantine's communist paramilitary groups were young workers, employees, or petty officials, and many of them were union activists before the war. Drew also underlines the fact that, while "embryonic" (p. 269) between 1957 and 1962, the PCA was still active, especially in Oran, Algiers, and Constantine, but also in France and in Czechoslovakia where it had 
foreign delegations. Furthermore, Drew points to communist activism in prison, and to the activism of prisoners' wives outside prison, throughout the wartime period. Hundreds of men and women maintained the PCA's spirit and ideas in jails and camps, sometimes struggling with anti-communism even if brotherhood and sisterhood with FLN inmates was prevalent.

It seems a pity that, considering the consistent focus on the PCA in preceding chapters, the communists cease to be at the centre of attention in the chapters dedicated to the war of independence, which turns into an historical synthesis of the national liberation struggle. Nonetheless, the conclusion offers interesting perspectives on communism in independent Algeria, and opens a debate about the legacy of the PCA in Algerian contemporary society. The author's assessment points to the importance of “its work in trade unions and other popular organisations, its promotion of a free press, its campaign against repression and its prison writings" (p. 278). Thus, Drew's work can be linked to several recent Ph.D. theses written by French historians about other "secondary" political parties of the Algerian anticolonial movement, which contribute to the presentation of a more complex picture of Algerian political pluralism in the late colonial era, the legacy of which in post-colonial Algeria still needs to be explored.

\section{Pierre-Jean Le Foll-Luciani}

Centre de Recherches Historiques de l'Ouest, Université Rennes 2 Place du recteur Henri Le Moal, 35043 Rennes cedex, France

E-mail: lefoll.luciani@gmail.com

Radkau, Joachim. The Age of Ecology. A Global History. Transl. by Patrick Camiller. Polity, Cambridge [etc.] 20I4. xiii, 546 pp. Ill. £30.00; $€$ 46.95. doi:10.1017/S0020859015000589

Joachim Radkau's Age of Ecology is a path-breaking contribution to global history. It is also one of the most important works in recent decades in the field of environmental history, as well as a significant intervention in the field of the history of global social movements. The book is, as Radkau himself points out (p. $\mathrm{x}$ ), a companion volume to his equally magnificent Nature and Power (Cambridge, 2008), which paid less attention to individual activists and movements than this current volume. The German environmental movement in particular has often been accused of lacking an awareness of its history - or even of being devoid of history and therefore historical relevance as such. Many contemporaries since the r 970 s have also argued that environmental movements have whipped up irrational fears, again especially with regard to Germany: talk about "German Angst” was an especially prominent means of denouncing environmentalism as a form of inward-looking romanticism with dangerous political consequences.

Radkau argues strongly against both allegations, and a short review cannot do justice to the wealth of material covered by the book. In his impressively wide-ranging first chapter, he provides a brief history of "environmentalism before the environmental movement": discussing fears of wood shortage alongside ideas developed by Jean-Jacques Rousseau as well as the German Romantics, the growth of concerns about public health in the context of 